\title{
Factors Affecting Taxpayer Compliance in Paying Pajak Bumi dan Bangunan (PBB P2) in Kutai Kartanegara
}

\author{
Omar Dhanny ${ }^{1}$, Muhammad Kadafi ${ }^{2}$, Hamzah Nur Pratama ${ }^{3}$ \\ \{odhanny@gmail.com ${ }^{1}$ \} \\ Politeknik Negeri Samarinda, Samarinda $a^{1,2,3}$
}

\begin{abstract}
This study purpose to determine the effect of tax knowledge, awareness of taxpayers, the level of trust in the government, and tax sanctions on compliance with PBB P2 taxpayers in Kota Bangun Sub-district of Kutai Kartanegara District. The population in this study is the PBB P2 taxpayer in Kota Bangun Sub-district of Kutai Kartanegara District. The sampling technique uses accidental sampling, the number of samples is 100 respondents. The data collection method used was a questionnaire. The study used an analytical tool in the form of an instrument test, a classic assumption test, multiple linear regression analysis. The results showed that tax knowledge and the level of trust in the government had a positive and significant effect on compliance with PBB P2 taxpayers, while awareness of taxpayers and tax sanctions had a positive and not significant effect on compliance with taxpayers.
\end{abstract}

Keywords: Taxpayer compliance, taxation knowledge, taxpayer awareness, level of trust in the government, and tax sanctions

\section{Introduction}

Taxes as one of the largest sources of funding in the implementation and enhancement of national development in the context of increasing the prosperity and welfare of the people. The construction of facilities and infrastructure is carried out with the aim of being able to boost economic growth and job opportunities, so that equitable development can be achieved [12]. Taxes are considered very important, so the Indonesian government needs to take various efforts in collecting and managing these taxes properly so that the targeted tax revenue can be achieved optimally and even exceed the targets set by the government.

Taxes can be divided into 2 (two) types, namely Central Taxes and Regional Taxes. There are various kinds of Regional Taxes that have been set by the government, one of which is Pajak Bumi dan Bangunan (PBB-P2). Judging from the current implementation of tax collection by local governments, it is not uncommon for the realization of rural and urban land and building tax revenues not to reach the predetermined tax targets. Based on an informal report from the source https://nasional.kontan.co.id states that throughout the 2015-2019 period, PBB revenue decreased with an average growth of $-10.4 \%$ per year. It could be that one of the reasons why this condition occurs is due to the non-compliance of the taxpayer in carrying out its obligations.

Rahayu [10] states that taxation conditions that require the active participation of taxpayers in carrying out their taxation require high taxpayer compliance, namely compliance in fulfilling 
tax obligations. Based on data obtained from the Regional Revenue Agency of Kutai Kartanegara Regency, the realization of revenue from Rural and Urban Land and Building Taxes in Kota Bangun District in 2019 is Rp. 156,258,546.00, while the revenue target that has been set is Rp. 559,141,361.00. This indicates that the Kota Bangun District actually has great potential for regional income from PBB-P2, in fact the revenue target is still very far to be achieved. This field fact is interesting to study, namely what factors affect the non-compliance of P2 PBB taxpayers, so that later the Kutai Kartanegara Regency government can make a new strategy to increase PBB-P2 revenue in the following year.

The formulation of the research problem is as follows:

1. Does knowledge of taxation have a positive and significant effect on taxpayer compliance in paying PBB P2 Taxes in Kota Bangun District, Kutai Kartanegara Regency?

2. Does taxpayer awareness have a positive and significant effect on taxpayer compliance in paying PBB P2 Taxes in Kota Bangun District, Kutai Kartanegara Regency?

3. Does the level of trust in the government have a positive and significant effect on taxpayer compliance in paying PBB P2 Taxes in Kota Bangun District, Kutai Kartanegara Regency?

4. Does the tax sanction have a positive and significant effect on taxpayer compliance in paying PBB P2 Tax in Kota Bangun District, Kutai Kartanegara Regency?

5. Do tax knowledge, taxpayer awareness, level of trust in the government, and tax sanctions together have a positive and significant effect on taxpayer compliance in paying PBB P2 Tax in Kota Bangun District, Kutai Kartanegara Regency?

\section{Method}

This research is quantitative research. The type of data used in this study is primary data. The data source of this research uses data from the distribution of questionnaires filled out by PBB P2 taxpayers in Kota Bangun District. The population in this study were all PBB P2 taxpayers in Kota Bangun District. The sampling technique used accidental sampling technique with a sample size of 100 people. The data analysis tools used instrument test (validity test and reliability test), classical assumption test (normality test, heteroscedasticity test, and multicollinearity test), multiple linear regression analysis, and hypothesis testing (t statistical test, F statistical test, correlation coefficient, and the coefficient of determination).

\section{Results and Discussion}

\subsection{Validity test}

Based on the validity test Table 1, it can be seen that all statement items used in this research questionnaire are valid. This is evidenced by the fact that all statement items have $r_{\text {count }}$ values that are greater than the $r_{\text {table }}$ value and are positive. 
Table 1. Validity test

\begin{tabular}{lcccc}
\hline \multicolumn{1}{c}{ Variable } & Item & $\mathbf{r}_{\text {count }}$ & rtable & Information \\
\hline Tax Knowledge (X1) & X1.1 & 0,671 & 0,165 & Valid \\
& X1.2 & 0,655 & 0,165 & Valid \\
& X1.3 & 0,574 & 0,165 & Valid \\
& X1.4 & 0,613 & 0,165 & Valid \\
& X1.5 & 0,704 & 0,165 & Valid \\
\hline Taxpayer Awareness & X2.1 & 0,859 & 0,165 & Valid \\
(X2) & X2.2 & 0,839 & 0,165 & Valid \\
\hline Level of Trust in & X3.1 & 0,672 & 0,165 & Valid \\
Government (X3) & X3.2 & 0,731 & 0,165 & Valid \\
& X3.3 & 0,721 & 0,165 & Valid \\
& X3.4 & 0,659 & 0,165 & Valid \\
\hline Tax Sanctions (X4) & X4.1 & 0,723 & 0,165 & Valid \\
& X4.2 & 0,669 & 0,165 & Valid \\
& X4.3 & 0,593 & 0,165 & Valid \\
& X4.4 & 0,618 & 0,165 & Valid \\
& X4.5 & 0,572 & 0,165 & Valid \\
\hline Taxpayer & Y.1 & 0,720 & 0,165 & Valid \\
Compliance (Y) & Y.2 & 0,765 & 0,165 & Valid \\
& Y.3 & 0,798 & 0,165 & Valid \\
\cline { 2 - 5 }
\end{tabular}

\subsection{Reliability test}

Based on the reliability test Table 2, it can be seen that all variables used in this research questionnaire are reliable. Therefore, the statement items on each of the research variables are feasible to be used as a measuring tool.

Table 2. Reliability test

\begin{tabular}{clccc}
\hline No & \multicolumn{1}{c}{ Variable } & Cronbach Alpha & Standard & $\begin{array}{c}\text { Informatio } \\
\text { n }\end{array}$ \\
\hline 1. & Tax Knowledge (X1) & 0,648 & 0,60 & Reliable \\
2. & Taxpayer Awareness (X2) & 0,612 & 0,60 & Reliable \\
3. & Level of Trust in Government (X3) & 0,644 & 0,60 & Reliable \\
4. & Tax Sanctions (X4) & 0,628 & 0,60 & Reliable \\
5. & Taxpayer Compliance (Y) & 0,625 & 0,60 & Reliable \\
\hline
\end{tabular}

\subsection{Normality test}

Based on the results of the normality test using the One-Sample Kolmogorov-Smirnov Test above, it can be seen that the Kolmogorov-Smirnov value is 0.072 and significant at 0.200 (Table 3). This means $0.200>0.05$, so it can be concluded that the residual data is normally distributed. 
Table 3. Normality test

\begin{tabular}{lcc}
\hline Variable & Test Statistic & Asymp. Sig. (2-tailed) \\
\hline The Influence of Taxation Knowledge (X1), Taxpayer & & \\
Awareness (X2), Level of Trust in Government (X3), and & 0,072 & 0,200 \\
Tax Sanctions (X4) on Taxpayer Compliance (Y) & & \\
\hline
\end{tabular}

\subsection{Heteroskedasticity test}

Based on the Table 4 of heteroscedasticity test results above, it can be seen that the significance value of all independent variables is above 0.05 . This shows that the regression model does not occur heteroscedasticity.

Table 4. Heteroskedasticity test

\begin{tabular}{lccc}
\hline \multicolumn{1}{c}{ Independent Variable } & tcount & Sig. & Information \\
\hline Tax Knowledge (X1) & 0,008 & 0,993 & Heteroscedasticity does not occur \\
Taxpayer Awareness (X2) & 1,080 & 0,283 & Heteroscedasticity does not occur \\
Level of Trust in Government (X3) & $-1,791$ & 0,077 & Heteroscedasticity does not occur \\
Tax Sanctions (X4) & $-1,034$ & 0,304 & Heteroscedasticity does not occur \\
\hline
\end{tabular}

\subsection{Multicollinearity test}

Based on the multicollinearity test results Table 5, it can be seen that all independent variables have a tolerance value of more than 0.10 . In addition, all independent variables when viewed from the VIF value also have a value less than 10 . Thus, it can be concluded that the regression model in this study does not occur multicollinearity.

Table 5. Multicollinearity test

\begin{tabular}{lccc}
\hline \multicolumn{1}{c}{ Independent Variable } & Tolerance & VIF & Information \\
\hline Tax Knowledge (X1) & 0,758 & 1,319 & Multicollinearity does not occur \\
\hline Taxpayer Awareness (X2) & 0,871 & 1,148 & Multicollinearity does not occur \\
\hline Level of Trust in Government (X3) & 0,735 & 1,361 & Multicollinearity does not occur \\
\hline Tax Sanctions (X4) & 0,755 & 1,324 & Multicollinearity does not occur \\
\hline
\end{tabular}

\subsection{Multiple Linear Regression Analysis}

Based on multiple linear regression analysis showed on Table 6.

Table 6. Multiple linear regression analysis

\begin{tabular}{lllll}
\hline Independent Variable & $\begin{array}{l}\text { Coefficient } \\
\text { Regression }\end{array}$ & thitung & Sig. & Information \\
\hline Constant & 3,162 & 2,143 & 0,035 & \\
Tax Knowledge (X1) & 0,225 & 3,349 & 0,001 & H1 be accepted \\
Taxpayer Awareness (X2) & 0,013 & 0,106 & 0,916 & H2 not accepted \\
Level of Trust in Government (X3) & 0,223 & 2,724 & 0,008 & H3 be accepted \\
Tax Sanctions (X4) & 0,076 & 1,086 & 0,280 & H4 not accepted \\
\hline Fhitung & & 11,075 & 0,000 & H5 be accepted \\
R & & 0,564 & & \\
R Square & 0,318 & & \\
Adjusted R Square & 0,289 & & \\
\hline
\end{tabular}


Based on the multiple linear regression analysis table above, the regression model equation in this study is obtained as follows:

$$
Y=3,162+0,225 X 1+0,013 X 2+0,223 X 3+0,076 X 4
$$

Based on table 6 above, it can be interpreted as follows:

a. The tax knowledge variable has a t-count of 3.349 with a significance of 0.001 . The value of tcount 3.349> ttable value of 1.985 and a significance of $0.001<0.05$, so it can be concluded that partially the tax knowledge variable has a significant effect on taxpayer compliance in Kota Bangun District, Kutai Kartanegara Regency. Thus, H1 is accepted.

b. Taxpayer awareness variable has a t-count value of 0.116 with a significance of 0.906 . The tcount value 0.116 <ttable value 1.985 and significance $0.906>0.05$, so it can be concluded that partially the taxpayer awareness variable does not significantly influence taxpayer compliance in Kota Bangun District, Kutai Kartanegara Regency. Thus, H2 was rejected. This can happen because there are other variables that are not explained in more detail in this study.

c. The variable level of trust in the government has a tcount of 2.724 with a significance of 0.008 . The value of tcount $2.724>$ ttable value of 1.985 and a significance of $0.008<0.05$, so it can be concluded that partially the variable level of trust in the government has a significant effect on taxpayer compliance in Kota Bangun District, Kutai Kartanegara Regency. Thus, H3 is accepted.

d. The tax sanction variable has a tcount of 1.086 with a significance of 0.280 . The tcount value is 1.086 <ttable value 1.985 and the significance is $0.280>0.05$, so it can be concluded that partially the tax sanction variable has no significant effect on taxpayer compliance in Kota Bangun District, Kutai Kartanegara Regency. Thus, H4 was rejected. This can happen because there are other variables that are not explained in more detail in this study.

Based on the data from the results of table 6 above, it can be seen that the Fcount value is 11.075 with a significance level of 0.000 . This shows that the Fcount value of 11.075 is greater than the Ftable value of 2.467 and the significance level of 0.000 is less than 0.05 . Thus, it can be concluded that H5 is accepted. This shows that tax knowledge, taxpayer awareness, level of trust in the government, and tax sanctions have a positive and significant effect simultaneously on the compliance of PBB P2 taxpayers in Kota Bangun District, Kutai Kartanegara Regency.

Based on table 6 above, it can be seen that the independent variable has a correlation coefficient (R) of 0.564 or $56.4 \%$. This shows that the independent variable has a level of relationship that is in the category of correlation value $0.50 \leq \mathrm{r} \leq 0.79$, meaning that the level of the relationship of the independent variable can be said to be moderate positively to influence the dependent variable in this study.

Based on table 6 above, it can be seen that the coefficient of determination (R2) of the independent variable is 0.289 or $28.9 \%$. Thus, it can be concluded that tax knowledge, taxpayer awareness, level of trust in the government, and tax sanctions affect the compliance of PBB P2 taxpayers in Kota Bangun District, Kutai Kartanegara Regency, only 28.9\%. Meanwhile, the remaining $71.1 \%$ is influenced by other variables outside the model that were not examined in this study. 


\subsection{Discussion}

\subsubsection{The influence of tax knowledge on taxpayer compliance of pbb p2 in kota bangun district, kutai kartanegara regency.}

Based on the results of data processing in the $t$ statistical test table, it can be seen that the previously proposed hypothesis was accepted. The positive effect indicates that taxation knowledge is directly proportional or unidirectional to taxpayer compliance, while the significant effect indicates that the P2 PBB taxpayer in Kota Bangun District, Kutai Kartanegara Regency has good tax knowledge to contribute to increasing compliance with paying PBB-P2.

This can happen because the P2 PBB Taxpayer in Kota Bangun District, Kutai Kartanegara Regency already knows the flow of registering to become a Taxpayer, the basis for imposition of taxes, matters relating to Tax Returns Payable (SPPT), tax rates that must be paid and how to pay it, how important the tax they pay will be used for the benefit of the government in building facilities and infrastructure for the progress of the country's development, to the applicable tax regulations and other knowledge.

This result means that the higher the level of tax knowledge possessed by the taxpayer, the higher the level of taxpayer compliance. The results of this study which state that taxation knowledge has a positive and significant effect on taxpayer compliance in paying PBB-P2 is in line with previous research conducted by Dewi [3], Setiono [11], and Ernawati \& Afifi [4].

\subsubsection{The influence of taxpayer awareness on taxpayer compliance with pbb p2 in kota bangun district, kutai kartanegara regency.}

Based on the results of data processing in the t statistical test table, it can be seen that the previously proposed hypothesis was rejected. The positive effect indicates that the taxpayer's awareness is directly proportional or unidirectional to the taxpayer's compliance, while the insignificant effect indicates that the low level of self-awareness of the PBB P2 taxpayer in Kota Bangun Subdistrict, Kutai Kartanegara Regency which results in non-compliance taxpayers to pay PBB P2.

This can happen because many PBB P2 taxpayers in Kota Bangun Subdistrict, Kutai Kartanegara Regency are still reluctant to pay taxes on time, even in arrears for years. Taxpayers assume that in making payments they often face difficulties due to long trips that even cost a lot of money. This condition underlies the low compliance of PBB P2 taxpayer in Kota Bangun District, Kutai Kartanegara Regency.

This result means that if the level of taxpayer awareness is still low, the level of tax compliance is also low. The results of this study are in line with the results of research by Harlina [7] and Dewi [3]. However, the results of this study contradict the results of research by Alam [1] that taxpayer awareness has a positive and significant effect on taxpayer compliance.

\subsubsection{The influence of the level of trust in the government on the compliance of pbb p2 taxpayers in kota bangun district, kutai kartanegara regency.}

Based on the results of data processing in the t statistical test table, it can be seen that the previously proposed hypothesis was accepted. The positive effect indicates that the level of trust in the government is directly proportional to or unidirectional to taxpayer compliance, while the significant effect indicates that the P2 Taxpayers in Kota Bangun District, Kutai Kartanegara 
Regency pay taxes because they give confidence to the government to manage the amount of taxes paid.

This can happen because the P2 PBB Taxpayer in Kota Bangun District, Kutai Kartanegara Regency has the belief that the existing government and law are running well. Taxpayers pay taxes because they trust politicians and people's representatives who have carried out their functions and authorities properly. In addition, the belief that tax collection will be reallocated to the people is also a consideration for taxpayers to pay their obligations.

This result means that if the level of trust in the government provided by the taxpayer is higher, the higher the level of compliance of the P2 PBB Taxpayer for discipline to pay the tax payable. Thus, taxpayers would want the government not to commit acts that would disappoint the public and lose confidence in the government. The results of this study are in line with previous research conducted by Setiono [11] and Yuliansyah, et al. [16]. However, Wijayanti \& Sasongko [14] state the results of the research are otherwise.

\subsubsection{The effect of tax sanctions on pbb p2 taxpayer compliance in kota bangun district, kutai kartanegara regency.}

Based on the results of data processing in the $t$ statistical test table, it can be seen that the previously proposed hypothesis was rejected. The positive effect indicates that tax sanctions are directly proportional to or unidirectional to taxpayer compliance, while the insignificant effect indicates that tax sanctions are not burdensome and do not become a threat to taxpayers not to carry out their tax obligations.

This can happen because the P2 PBB Taxpayer in Kota Bangun Subdistrict, Kutai Kartanegara Regency feels that the tax sanctions applied are not burdensome and the application of these tax sanctions is deemed not carried out firmly by the tax officials. This is because taxpayers consider tax sanctions to be limited to formality and written regulations, so that there is no deterrent effect for taxpayers who commit violations or negligence.

This result means that the lower the tax sanctions given, the lower the level of tax compliance. This results in no tools or guarantees to increase tax revenue effectively. The results of this study are in line with the results of research conducted by Ernawati \& Afifi [4], Yuliansyah et al. [16], and Harlina [7].

\subsubsection{The Influence of Tax Knowledge, Taxpayer Awareness, Trust Level in Government, and Tax Sanctions on PBB P2 Taxpayer Compliance in Kota Bangun District, Kutai Kartanegara Regency.}

Based on the results of data processing in the F statistical test table, it can be seen that the previously proposed hypothesis was accepted. This result means that if tax knowledge, taxpayer awareness, level of trust in the government, and tax sanctions are simultaneously increasing, the compliance of PBB P2 taxpayers in Kota Bangun District, Kutai Kartanegara Regency will increase as well.

\section{Conclusion}

Based on the results of the tests and discussions that have been carried out, several conclusions can be drawn as follows: 
a. Tax Knowledge Variable (X1) has a positive and significant effect on PBB P2 Taxpayer compliance in Kota Bangun District, Kutai Kartanegara Regency. This result means that the higher the level of tax knowledge possessed by the taxpayer, the higher the level of taxpayer compliance.

b. Taxpayer Awareness (X2) has a positive and insignificant effect on the compliance of PBB P2 taxpayers in Kota Bangun District, Kutai Kartanegara Regency. This result means that if the level of taxpayer awareness is still low, the level of tax compliance is also low.

c. The level of trust in the government variable (X3) has a positive and significant effect on the compliance of PBB P2 taxpayers in Kota Bangun District, Kutai Kartanegara Regency. This result means that if the level of trust in the government provided by the taxpayer is higher, the higher the level of compliance of the P2 PBB Taxpayer for discipline to pay the tax payable.

d. Tax Sanctions Variable (X4) has a positive and insignificant effect on the compliance of PBB P2 taxpayers in Kota Bangun District, Kutai Kartanegara Regency. This result means that the lower the tax sanctions given, the lower the level of tax compliance.

e. Taxation Knowledge Variable (X1), Taxpayer Awareness (X2), Level of Trust in Government (X3), and Tax Sanctions (X4) together have a positive and significant effect on PBB P2 Taxpayer compliance in Kota Bangun District, Kutai Regency. Kartanegara. This result means that if tax knowledge, taxpayer awareness, level of trust in the government, and tax sanctions are simultaneously increasing, the compliance of PBB P2 taxpayers in Kota Bangun District, Kutai Kartanegara Regency will increase as well.

\section{References}

[1] Alam, Syamsu. (2014). "Pengaruh Sosialisasi Pajak, Kesadaran Wajib Pajak, dan Sanksi Pajak Terhadap Kepatuhan Wajib Pajak Dalam Membayar Pajak Bumi dan Bangunan di Desa Baringeng Kecamatan Lilirilau Kabupaten Soppeng”. Skripsi, Universitas Islam Negeri Alauddin Makassar.

[2] Badan Pusat Statistik Kabupaten Kutai Kartanegara. (2020). "Kecamatan Kota Bangun dalam Angka $2019 "$ (https://kukarkab.bps.go.id/publication/2019/09/26/b16dadecc5ea9193e2c5a8ae/kecamatan-kotabangun-dalam-angka-2019, diakses pada tanggal 21 Juni 2020).

[3] Dewi, Dhinar Cahya Kusuma. (2018). "Analisis Faktor-Faktor yang Mempengaruhi Kepatuhan Wajib Pajak Bumi dan Bangunan di Kabupaten Wonogiri". Jurnal, Universitas Muhammadiyah Surakarta.

[4] Ernawati, N., \& Afifi, Z. (2018). "Pengaruh Pengetahuan Perpajakan dan Sanksi Perpajakan terhadap Kepatuhan Wajib Pajak dengan Religiusitas sebagai Variabel Pemoderasi". Jurnal, Universitas Muria Kudus.

[5] Gusar, H. S. (2015). Pengaruh Sosialisasi Pemerintah, Pengetahuan Perpajakan, Sanksi Pajak, Kesadaran Wajib Pajak, dan Kualitas Pelayanan Terhadap Kepatuhan Wajib Pajak dalam Membayar Pajak Bumi dan Bangunan (Kecamatan Bengkong). Jurnal. Universitas Riau.

[6] Handayani, S. W., Faturokhman, A., \& Pratiwi U. (2014). Faktor-Faktor yang Mempengaruhi Kemauan Membayar Pajak Wajib Pajak Orang Pribadi yang Melakukan Pekerjaan Bebas. Jurnal. Universitas Jendral Soedirman.

[7] Harlina, Intan W. (2016). "Faktor-Faktor yang Memengaruhi Kepatuhan Wajib Pajak dalam Melakukan Pembayaran Pajak Bumi dan Bangunan Pedesaan dan Perkotaan (Studi Empiris pada Wajib Pajak Bumi dan Bangunan Pedesaan dan Perkotaan di Daerah Istimewa Yogyakarta)". Jurnal. Universitas Muhammadiyah Yogyakarta. 
[8] Kontan.co.id. (2019). "Tren Penerimaan Pajak Bumi dan Bangunan Kian Melambat, Ini Sebabnya". (https://nasional.kontan.co.id/news/tren-penerimaan-pajak-bumi-dan-bangunan-kian-melambat-inisebabnya, diakses pada tanggal 20 Desember 2019).

[9] Parera, A. M. W. (2017). "Pengaruh Kesadaran Wajib Pajak, Sanksi Perpajakan, Pengetahuan Perpajakan, dan Pelayanan Fiskus Terhadap Kepatuhan Wajib Pajak Bumi dan Bangunan". Jurnal Akuntansi, Universitas Sarjanawiyata.

[10] Rahayu, S. K. (2010). Perpajakan Indonesia. Yogyakarta: Graha Ilmu.

[11] Setiono, Sujatmiko Dwi. (2018). "Analisis Faktor-Faktor yang Mempengaruhi Kepatuhan Pajak Bumi dan Bangunan". Skripsi, Universitas Islam Indonesia.

[12] Sudirman, R., \& Amiruddin, A. (2015). Perpajakan Pendekatan Teori dan Praktek. Malang: Empatdua Media.

[13] Republik Indonesia, Undang-Undang Nomor 28 Tahun 2009 tentang Pajak Daerah dan Retribusi Daerah.

[14] Wijayanti, D., \& Sasongko, N. (2017). Pengaruh Pemahaman, Sanksi Perpajakan, Tingkat Kepercayaan Pada Pemerintah dan Hukum Terhadap Kepatuhan dalam Membayar Wajib Pajak (Studi Wajib Pajak pada Masyarakat di Kelurahan Pajang Kecamatan Laweyan Surakarta. Jurnal. Universitas Muhammadiyah Surakarta.

[15] Wirapati, I Putu W., \& Jati, I K. (2014). Faktor-Faktor yang Memengaruhi Kepatuhan Pengrajin dalam Memiliki NPWP di Kabupaten Gianyar. Jurnal Akuntansi. Universitas Udayana.

[16] Yuliansyah, R., Setiawan, D. A., \& Mumpuni, R. S. (2019). Pengaruh Pemahaman, Sanksi Perpajakan, dan Tingkat Kepercayaan pada Pemerintah Terhadap Kepatuhan Wajib Pajak dalam Membayar PBB-P2 (Studi Empiris Wajib Pajak PBB-P2 Kecamatan Jatinegara). Jurnal. Sekolah Tinggi Ilmu Ekonomi Indonesia. 